e-ISSN: 2686-522X, p-ISSN: 2686-5211

DOI: https://doi.org/10.38035/jafm.v1i5

Received: 04 October 2020, Revised: 13 October 2020, Publish: 04 November 2020

https://creativecommons.org/licenses/by/4.0/

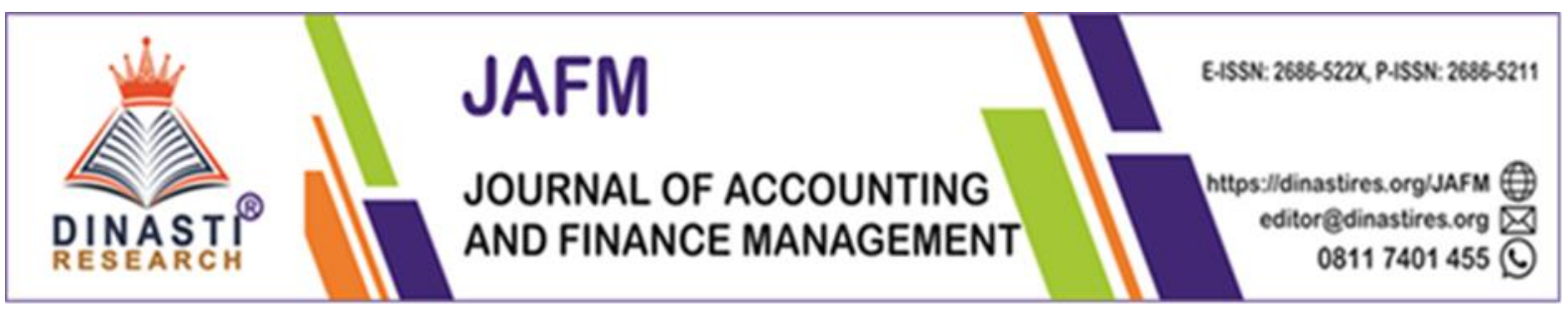

\title{
The Effects of Liquidity, Solvency, and Profitability on Stock Price (a Study in PT. Telekomunikasi Indonesia Tbk. Period of 2004-2018)
}

\author{
Kusnandar ${ }^{1)}$, Maya Sari ${ }^{2}$ \\ ${ }^{1)}$ Magister of Management UPI, West Java, Indonesia, kusnandar@upi.edu \\ ${ }^{2)}$ Magister of Management UPI, West Java, Indonesia, mayasari@ upi.edu
}

Corresponding author: Kusnandar ${ }^{1}$

\begin{abstract}
This study aims to determine the effect of liquidity, solvency and profitability on stock prices. The research was conducted at PT Telekomunikasi Indonesia Tbk during the period of 2004-2018. Through a multiple regression analysis, the effect of liquidity, solvency and profitability was investigated by measuring current ratio, debt to equity ratio, and return on assets effects on stock prices. The findings reveal that changes in liquidity, profitability, and solvency are able to explain the changes being occurred on the share price of PT Telkom Indonesia during the period. Out of the three determinants, profitability performance is the only determinant that has a significant impact on stock price. These findings indicate that profitability performance becomes one factor that is most considered by investors in making investment decisions. Further, the profitability performance is also able to provide positive signals to the investors regarding the company prospects in the future.
\end{abstract}

Keywords: Liquidity, Solvency, Profitability, Stock Prices

\section{INTRODUCTION}

The phenomenon of stock prices in Indonesia has been fluctuating. In general, in 2013, most of the company's stock prices decreased, while in 2017 the share price increased. In the telecommunication sector, share prices in 2013 increased, although there were several companies that experienced a decline. Meanwhile, in 2016, the stock prices of telecommunication companies mostly decreased. A significant decline in share prices generally occurred in 2018. In PT. Telkom Indonesia, the share price decreased in 2008 and it got better in 2014 and 2016 where their share price increased. In 2018, share prices in PT. Telkom Indonesia continue to decline. 
The purpose of establishing a company is to maximize company value. Company value can be referred to the views and thoughts of investors on the level of success the company can get at present time and in the future. By maximizing company value, the company will automatically maximize the satisfaction of its shareholders. This may be good news for the company as the shareholders will obviously not hesitate to invest their funds in the company. In other words, high firm value will be followed by an increase in shareholder wealth (Bringham and Houston, 2006). The value of the company is reflected in its share price. The stock price is an indicator of the success of company management. The continuous improvement of stock price of a company will make company good image to the investors or potential investors, which at the same time will reflect the company success in managing its business (Zuliarni, 2012).

According to the signal theory, corporate activity provides information to investors about the prospects for substantial future returns. This information acts a signal the management announces to the public to declare the company potential prospects in the future. This signal theory discusses how signals of success or failure in management (agent) should be conveyed to the owners of capital (principle). The submission of financial statements can be considered as a signal that is able to clarify whether the agent has acted based on the contract or not. Signal theory also predicts whether or not the announcement of the effect on stock prices and dividend is positive (Susilowati, 2011). According to Francis (1988), a fundamental analysis can be used to estimate stock prices by analyzing the financial and economic conditions of the companies who issue the shares. Fundamental analysis states that the value of share is strongly influenced by the performance of the company issuing the shares (Murtanto and Harkivent, 2000).

An ample of tests of signal effects from financial performance has been carried out, such as studies by Tahu \& Susilo (2017) Susanto (2012), and Prayitno (2008). The previous studies indicate that there are three indicators that are mostly found in testing the effects of financial performance signals on stock prices, namely liquidity, solvency, and profitability.

Liquidity relates to the extent to which the company ability to complete its short-term obligations or which must be paid immediately. A company that can complete its financial obligations on time means that the company is in a liquid state. A liquid company has a means of payment or current assets that are greater than the debt smoothness (Komala \& Nugroho, 2013). Studies conducted by Ojah et al. (2019), Mittelstaedt and Warshawsky (1993) state that the liquidity ratio has a significant effect on stock prices. On the contrary, Susanto (2012) and Susilawati (2012) studies reveal that liquidity results do not affect stock prices.

Solvency can be referred to the ratio of a company ability to meet its financial obligations. The solvency ratio leads to a high level of risk faced by shareholders with the possibility of their inability to pay their obligations (Barakat, 2014). Research conducted by Ojah et al. (2019) and Murniati (2016) state that the solvency ratio has a significant effect on stock prices, whereas Susanto (2012), Alvionita (2017) and Valintino \& Sularto (2013) in their research show different results that solvency has no effect on stock prices.

Profitability is the company's ability to generate profits using assets or models. According to Shaheen and Malik (2012), profitability is the amount of money a company can make with whatever resources they have. Barakat (2014) and Menaje (2012) in their study 
found that profitability ratio has a significant effect on stock prices. Having the same sound, studies conducted by Valintino and Sularto (2013) and Susanto (2012) show that profitability has a significant impact on stock prices.

Departing from the empirical gaps shown gained from previous studies, the present study will try to investigate the signal effects of liquidity, profitability, and solvency on stock price in PT Telkom Indonesia. This site is chosen since it is one of companies that owns the blue chip category share.

\section{LITERATURE REVIEW}

\section{Signalling Theory}

The theory underlying this research is signal theory. This theory serves to make it easier for investors to develop the shares needed by company management in determining the direction or prospects of the company in the future (Hanani, 2011). According to Krisna (2013), signal theory indicates the existence of asymmetryc information between company management and related and authorized parties.

\section{Capital market}

The capital market can be formally defined as a market for various financial instruments or long-term securities that can be traded both in the form of debt and equity, whether issued by the government, public authorities, or private companies (Kesuma, 2019).

According to Kurniawan and Isynurwardana (2015), the capital market relates to a market for various long-term tradable financial instruments, such as bonds (obligations), equities (stocks), mutual funds, derivative instruments, and other instruments.

\section{Stock price}

According to Rinati (2012) shares can be defined as a sign of participation or ownership of a person or entity in a company. A share is a sheet of paper which explains that the owner of the paper is the owner. According to Husnan and Pudjiastuti (2012), share price is the present value of income that investors will receive in the future.

Share prices can be divided into three categories, namely:

a. Nominal Price

The price that is stated in the share certificate determined by the issuer to value each share being issued

b. Prime Price

This price is the price when the share price is listed in the stock exchange.

c. Market price

Market price is the selling price from one investor to another. This price formed after the shares are listed in the stock exchange

\section{Liquidity Ratio}

Liquidity is an indicator of the company's ability to pay all its financial obligations on due date (Mulyadi, 2006). This ratio assumes that current assets are the main source of money to complete their long-term liabilities.

One of the liquidity ratios is the current ratio. Current Ratio describes the ability of all current assets to guarantee all current debt (Mulyadi, 2006). 


\section{Solvency Ratio}

Solvency describes the company's ability to pay its long-term obligations or obligations if the company is liquidated (Susilawati, 2013). These ratios can be calculated from long-term items such as fixed assets and long-term debt.

Debt Equity Ratio is one of solvency ratio. Noverio and Dewayanto (2011) suggest that the debt to equity ratio relates to the ratio of the amount of debt to equity that measures the percentage of use of funds originating from creditors.

\section{Profitability Ratio}

According to Amanza (2012), profitability is referred to the company's ability to earn profits in relation to sales, total assets, and own capital. One of the profitability ratios is Return on Assets (ROA). Return on Asset (ROA) is part of the profitability ratio in analyzing the financial statements of the company's financial performance reports.

In addition, Prayitno (2008) asserts that Return on Assets (ROA) is one of the ratios that can be used in measuring the level of profit a company receives. High ROA indicates that the company's total assets generate high net income for shareholders.

\section{Hypotheses}

Based on the aforementioned theories, the hypotheses of the present study are formulated as follow:

$\mathrm{H}_{1}$ : There is a significant effect of Liquidity on stock price

$\mathrm{H}_{2}$ : There is a significant effect of Solvency on stock prices

$\mathrm{H}_{3}$ : There is a significant effect of Profitability on stock prices

$\mathrm{H}_{4}$ : There is a significant effect of Liquidity, Solvency, and Profitability simultaneously on stock prices

\section{RESEARCH METHODS}

The study was set as descriptive verification study. The descriptive method was employed to describe the variables being studied. Meanwhile, verification method was aimed to double-check the truth of previous research results. The data were collected through several data collection instruments namely documentation, meaning that the researcher collects the financial statements of PT. Telekomunikasi Indonesia Tbk. and other relevant data to be analyzed. Further, this study uses multiple regression analysis methods to test hypotheses. This was conducted by previously carrying out classical assumption tests that consists of normality test, autocorrelation test, multicollinearity test and heterodedasticity test so that the multiple regression results will not be biased.

The variables being examined in this study consisted of three independent variables, namely liquidity, solvency, and profitability and one dependent variable, namely stock price. The data were obtained from the annual financial reports that have been published by PT. Telekomunikasi Indonesia Tbk. The operational research variables are described as follow:

Table 1. Operational Variable

\begin{tabular}{lllll}
\hline No. & Variable & \multicolumn{1}{c}{ Indicator } & \multicolumn{2}{c}{ Formula } \\
\hline 1. & Stock price & Closing stock price & & \\
\hline 2. & Liquidity & Current Ratio & CR $=\frac{\text { Current Assets }}{\text { Current Liabilities }} \times 100 \%$ & (Mulyadi, 2006) \\
\hline
\end{tabular}




\begin{tabular}{lllll}
\hline 3. & Solvency & Debt Equity Ratio (DER) & DER $=\frac{\text { Total Kewajiban }}{\text { Total Equity }} \times 100 \%$ & (Mulyadi, 2006) \\
\hline 4. Profitability & Return on Asset (ROA). & ROA $=\frac{E A T}{\text { Total Aktiva }} \times 100 \%$ & (Mulyadi, 2006) \\
\hline
\end{tabular}

\section{FINDINGS AND DISCUSSION}

\section{Normality Test}

The normality test aims to test whether in the regression model, both the dependent variable and the independent variable have a normal distribution or not. The normality test data in this study used the normal plot graph test. The points that are formed are better spread around the diagonal line and the direction of the distribution follows the direction of the diagonal line, otherwise the available data will not be normally distributed (Imam Ghozali, 2011).

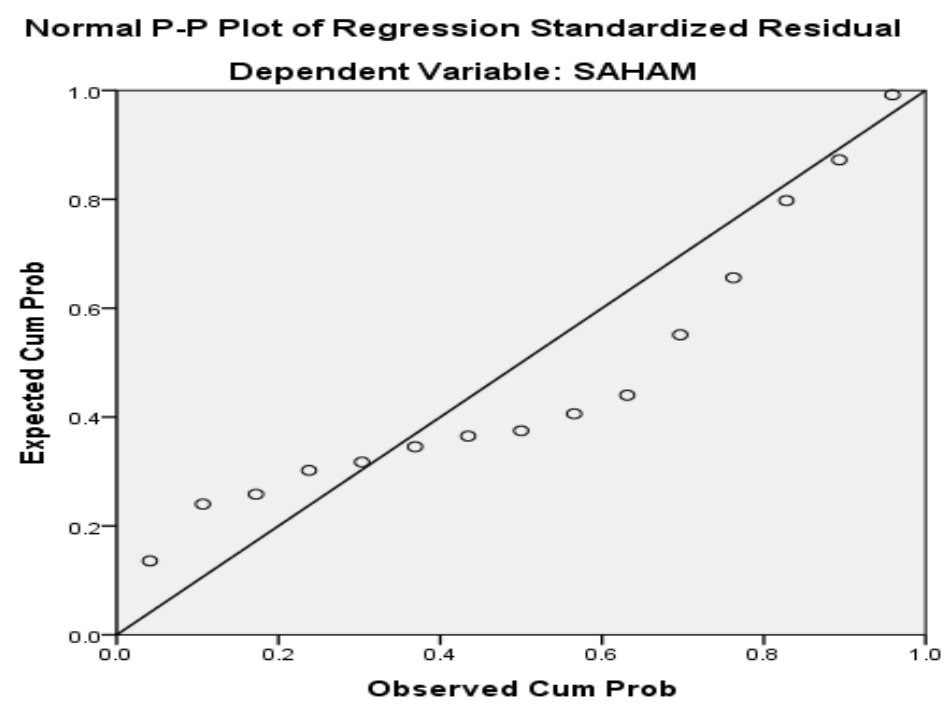

Figure 1. Normality Test Data

Source: SPSS Data Analysis

From the picture above, it can be seen that the data in the regression model is around the diagonal line, which means the data meets the data normality assumption. This data is supported by the results of the Shapiro-Wilk data normality test. Where the significant value is $0.115>0.05$, which means that the data is normally distributed

Table 2. Normality Test Data

Tests of Normality

\begin{tabular}{|c|c|c|c|}
\hline & \multicolumn{3}{|c|}{ Shapiro-Wilk } \\
\hline & Statistic & Df & Sig. \\
\hline SAHAM & .905 & 15 & .115 \\
\hline \multicolumn{4}{|c|}{ a. Lilliefors Significance Correction } \\
\hline
\end{tabular}

\section{Autocorrelation Test}

The autocorrelation test was intended to test whether in a multiple linear regression model there is a correlation between the confounding error in period $t$ with the error of the previous period ( $\mathrm{t}-1)$. To test the presence or absence of autocorrelation problems, the Durbin 
Watson test (DW test) can be performed by comparing the DW statistical value with the DW table (Mahapsari and Taman, 2013).

Table 3. Durbin Watson Test

\begin{tabular}{|c|c|c|c|c|c|}
\hline \multicolumn{6}{|c|}{ Model Summary $^{b}$} \\
\hline \multirow[t]{2}{*}{ Model } & \multicolumn{4}{|c|}{ Change Statistics } & \multirow{2}{*}{$\begin{array}{l}\text { Durbin- } \\
\text { Watson }\end{array}$} \\
\hline & $\begin{array}{l}\text { R Square } \\
\text { Change }\end{array}$ & F Change df1 & df2 & Sig. F Change & \\
\hline 1 & .755 & 11.320 & 11 & .001 & 1.211 \\
\hline \multicolumn{6}{|c|}{ a. Predictors: (Constant), ROA, CR, DER } \\
\hline \multicolumn{6}{|c|}{ b. Dependent Variable: SAHAM } \\
\hline
\end{tabular}

From the table above, it can be seen that the value of the Durbin-Watson table with $\mathrm{k}$ $=3$ and $\mathrm{n}=15$ obtained the value of $\mathrm{dL}=0.814$ and $\mathrm{dU}=1.7501$. Since the Durbin-Watson value 1.211 lies between $\mathrm{dL}$ and $\mathrm{dU}$, a Run Test is necessary needed. The results of the Run Test test show the following results:

Table 4. Run Test

\begin{tabular}{ll}
\hline & Runs Test \\
\hline & $\begin{array}{l}\text { Unstandardized } \\
\text { Residual }\end{array}$ \\
\hline Test Value $^{\mathrm{a}}$ & -191.53287 \\
\hline Cases $<$ Test Value & 7 \\
\hline Cases $>=$ Test Value & 8 \\
\hline Total Cases & 15 \\
\hline Number of Runs & 10 \\
\hline$Z$ & .556 \\
\hline Asymp. Sig. (2-tailed) & .578 \\
\hline a. Median & \\
\hline Source: SPSS Data Analysis &
\end{tabular}

According to Ghozali (2011), the basis for making the Run Test decision is:

1. If the value is Asymp. Sig. (2-tailed) less than 0.05, this means that the residual data occurs systematically (there are signs of autocorrelation)

2. If the value is Asymp. Sig. (2-tailed) more than 0.05, this means that the residual data occurs randomly (there are signs of autocorrelation)

With the Asymp value. Sig. (2-tailed) of 0.578 that is higher than 0.05 , it can be concluded that there are no autocorrelation symptoms. Thus, linear regression analysis can be continued.

\section{Multicolinierity Test}

Multicollinearity test aims to test whether the regression found a relationship between independent variables or not. To detect the presence or absence of multicollinearity in the regression model, it can be seen from the tolerance value and the variance inflation factor (VIF) value. 
Table 5. Coefficient Tolerance and VIF Coefficients $^{\mathrm{a}}$

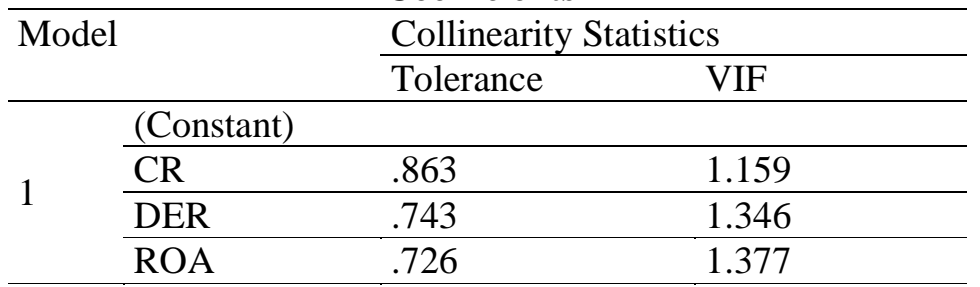

a. Dependent Variable: SAHAM

Source: SPSS Data Analysis

The multicollinearity test results in the table show that:

a. The VIF value of the Liquidity variable is $1.159<5$ and tolerance $0.863>0.1$, then the Liquidity variable is declared free of multicollinearity.

b. The VIF value of the Solvency variable is $1.346<5$ and tolerance $0.743>0.1$, then the Liquidity variable is declared free of multicollinearity.

c. The VIF value of the Profitability variable is $1.377<5$ and tolerance $0.726>0.1$, then the Profitability variable is declared free of multicollinearity.

\section{Heteroscedasticity Test}

This test aims to test whether in the regression model there is an inequality of variance from the residuals of one observation to another. The results of the heteroscedasticity test using a scatterplot graph are shown in the following figure:

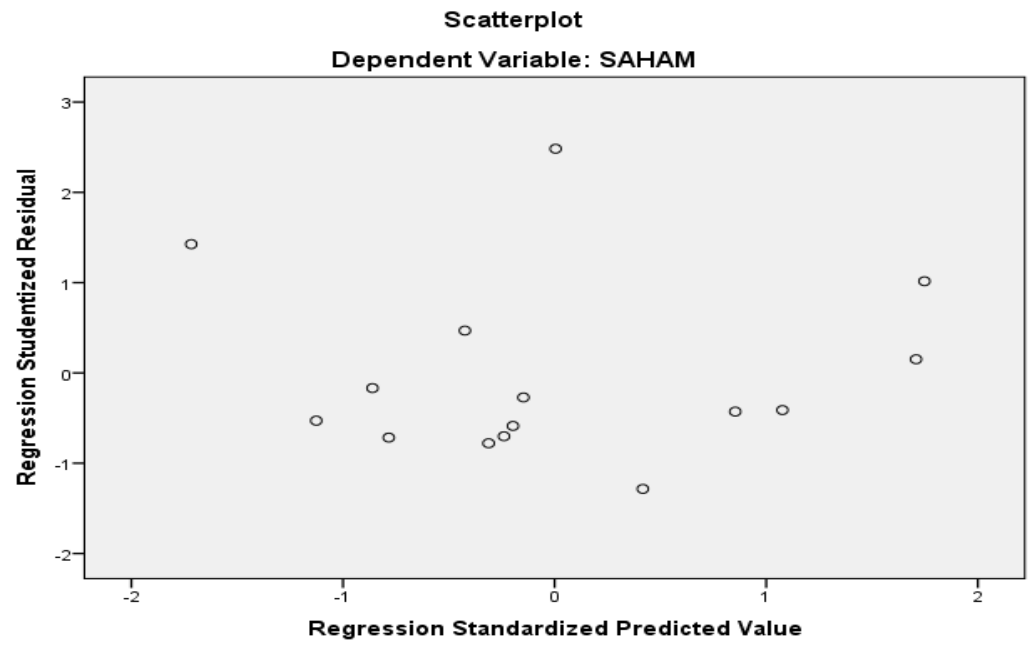

Figure 2. Heteroscedasticity Test Data

Source: SPSS Data Analysis

In the scatter plots graphic above, it can be seen that the dots are spread randomly, above or below the zero on the $\mathrm{Y}$ axis. Thus, it can be concluded that there is no heteroscedasticity problem in the regression model that is being used.

\section{Multiple Linear Regression Equation}

The regression equation model in this study is applied to test the effect of liquidity, solvency and profitability on stock prices. 
Table 6. Coefficients of Regression Equation

\begin{tabular}{llll}
\hline & \multicolumn{3}{c}{ Coefficients $^{\mathbf{a}}$} \\
\cline { 2 - 3 } Model & \multicolumn{2}{c}{ Unstandardized Coefficients $^{\text {B }}$} & Std. Error \\
\hline \multirow{3}{*}{1} & & -5920.153 & 1549.564 \\
\cline { 2 - 4 } & (Constant) & 1389.871 & 728.470 \\
\cline { 2 - 3 } & CR & 1764.943 & 880.088 \\
\cline { 2 - 3 } & DER & 42692.977 & 9407.695 \\
\cline { 2 - 3 } & ROA &
\end{tabular}

Source: SPSS Data Analysis

Thus, the multiple linear regression equation of this study is as follows:

$$
\hat{\mathrm{Y}}=-5920+1390 \mathrm{CR}+1765 \mathrm{DER}+42692 \mathrm{ROA}
$$

\section{Hypotheses Testing}

\section{a. Partial Hypotheses Testing}

Partial testing was conducted by using the $t$ test. The decision making was carried out by comparing the $t$ value of each regression coefficient with the $t$ Table value (critical value) and the significance value according to the significance level used in the study. The result can be seen in the following table.

Table 7. Coefficient T Count

\begin{tabular}{|c|c|c|c|c|c|c|}
\hline \multicolumn{7}{|c|}{ Coefficients $^{\mathrm{a}}$} \\
\hline \multirow{2}{*}{\multicolumn{2}{|c|}{ Model }} & \multicolumn{2}{|c|}{ Unstandardized Coefficients } & \multirow{2}{*}{$\begin{array}{c}\text { Standardized } \\
\text { Coefficients } \\
\text { Beta } \\
\end{array}$} & \multirow{2}{*}{$\mathbf{t}$} & \multirow{2}{*}{ Sig. } \\
\hline & & $\bar{B}$ & Std. Error & & & \\
\hline \multirow{4}{*}{1} & (Constant) & -5920.153 & 1549.564 & & -3.821 & .003 \\
\hline & $\mathrm{CR}$ & 1389.871 & 728.470 & .306 & 1.908 & .083 \\
\hline & DER & 1764.943 & 880.088 & .347 & 2.005 & .070 \\
\hline & $\mathrm{ROA}$ & 42692.977 & 9407.695 & .794 & 4.538 & .001 \\
\hline
\end{tabular}

Source: SPSS Data Analysis

From the results of the regression analysis, some descriptions can be seen as follows:

a. $\mathrm{T}$ count value of Liquidity Variable (CR) is 1.908 while the $\mathrm{T}$ Table is at the 5\% significant level is 2.2009. This calculation results show that the $\mathrm{T}$ count is lower than the $\mathrm{T}$ table $(1.908<2.2009)$ with the significance value 0.083 that is higher than 0.05 (H1 is rejected). Accordingly, it can be concluded that, partially, liquidity (CR) does not have a significant effect on stock prices.

b. The Solvency variable (DER) has a $\mathrm{T}$ value of 2.005 while the $\mathrm{T}$ table at the 5\% significant level is 2.2009. This calculation reveals that the $\mathrm{T}$ count is lower than the $\mathrm{T}$ table $(2.005<2.2009)$ with the significance value 0.070 that is higher than 0.05 ( $\mathrm{H} 2$ is rejected). Thus, it can be said that partially, solvency (DER) also has no significant effect on stock prices.

c. Meanwhile, the T count value of profitability variable (ROA) is 4.538 while the T table at $5 \%$ significant level is 2.2009 . This calculation shows that the $\mathrm{T}$ count is higher than the $\mathrm{T}$ table $(4.538>2.2009)$ and the significance value is 0.001 that is lower than 0.05 (H3 is accepted). Thus, it can be concluded that, partially, profitability (ROA) has a significant effect on stock prices. 


\section{b. Simultaneous Hypotheses Testing}

Simultaneous hypotheses testing was done by using the F test to determine the effect of the independent variables including liquidity, solvency and profitability simultaneously on the dependent variable stock price.

Table 8. ANOVA F Count

\begin{tabular}{lllllll}
\hline & \multicolumn{5}{c}{ ANOVA $^{\mathrm{a}}$} \\
\hline Model & $\begin{array}{l}\text { Sum } \\
\text { Squares }\end{array}$ & of df & Mean Square & F & Sig. \\
\hline \multirow{3}{*}{1} & Regression & 12243588.123 & 3 & 4081196.041 & 11.320 & $.001^{\mathrm{b}}$ \\
\cline { 2 - 7 } & Residual & 3965919.611 & 11 & 360538.146 & & \\
\cline { 2 - 6 } & Total & 16209507.733 & 14 & & & \\
\hline \multicolumn{2}{l}{ a. Dependent Variable: SAHAM } & & & \\
\hline
\end{tabular}

From the results of the regression analysis, it can be seen that simultaneously, the independent variables have a significant effect on the dependent variable. This can be proven from the calculated $\mathrm{F}$ value (11.320) with the $\mathrm{F}$ table value at the 5\% significant level is 3.59 . This result shows that the $\mathrm{F}$ count is higher than the $\mathrm{F}$ table $(11.320>3.59)$, and the significance value 0.001. is lower than 0.05 (H4 is accepted). Thus, it can be concluded that liquidity (CR), solvency (DER), and profitability (ROA) simultaneously have a significant effect on stock prices.

\section{Coefficient of Determination}

The coefficient of determination serves to see the extent to which all independent variables can explain the dependent variable.

Table 9. Determination Coefficient

\begin{tabular}{|c|c|c|c|c|}
\hline \multicolumn{5}{|c|}{ Model Summary $^{b}$} \\
\hline Model & $\mathrm{R}$ & R Square & $\begin{array}{l}\text { Adjusted } \\
\text { Square }\end{array}$ & $\begin{array}{l}\mathrm{R} \text { Std. Error of the } \\
\text { Estimate }\end{array}$ \\
\hline 1 & $.869^{\mathrm{a}}$ & .755 & .689 & 600.448 \\
\hline $\begin{array}{l}\text { a. Predi } \\
\text { b. Depe }\end{array}$ & $\begin{array}{l}: \text { (Const } \\
\text { t Varial }\end{array}$ & $\begin{array}{l}\text { RA, CR, D } \\
\text { HAM }\end{array}$ & & \\
\hline
\end{tabular}

Based on the results of the above calculations, it can be seen that the effect of the three independent variables (independent) on the share price variable is expressed by the coefficient of determination (R2), which is $68.9 \%$. This means that $68.9 \%$ of the variation in stock prices can be explained by variations in the current ratio, debt to equity ratio (DER) and return on assets (ROA). The remaining $31.1 \%$ may be explained by other variables.

\section{Discussion}

Based on the research results, it is obtained that the Liquidity value as measured by the current ratio has a $\mathrm{T}$ count value of 1.908 while the $\mathrm{T}$ Table is a significant level of 5\% of 2.2009, so that the calculation results show that the $\mathrm{T}$ count is lower than the $\mathrm{T}$ table $(1.908<2.2009)$ The significance value is 0.083 or it can be said that it is greater than 0.05 so that it rejects H1. Thus, it can be said that the current ratio partially does not have a significant effect on stock prices. This is in line with research conducted by Susanto (2012) 
and Susilawati (2012) which shows that liquidity results partially do not affect stock prices, but it is not in line with research conducted by Ojah et al. (2019) and Mittelstaedt \& Warshawsky (1993) where liquidity partially affects stock prices.

The results of the study of solvency as measured by the Debt to Equity Ratio (DER) have a $\mathrm{T}$ value of 2.005 while the $\mathrm{T}$ table is at the $5 \%$ significant level of 2.2009 , so that the calculation results show that the $\mathrm{T}$ count is lower than the $\mathrm{T}$ table $(2.005<2,2009)$ the significance value is 0.070 or it can be said that it is greater than 0.05 so that it rejects $\mathrm{H} 2$. Thus, it can be said that the Debt to Equity Ratio partially has no significant effect on stock prices. This is in line with research conducted by Susanto (2012), Alvionita (2017) and Valintino and Sularto (2013) which show that the results of partial solvency have no effect on stock prices, but are not in line with research conducted by Ojah et al. (2019) and Murniati (2016) where partially solvency affects stock prices.

The results of the research on Profitability as measured by Return on Assets (ROA) has $\mathrm{T}$ count value of 4.538 while the $\mathrm{T}$ Table at a significant level of $5 \%$ is 2.2009 . This results shows that the $\mathrm{T}$ count is higher than Table $\mathrm{T}(4.538>2,2009)$ with the significance value 0.001 that is lower than 0.05 (H3 is accepted). Thus, it can be concluded that Return on Assets (ROA), partially, has a significant effect on stock prices. This is in line with research conducted by Barakat (2014) and Menaje (2012) which show that profitability, partially, affects stock prices, however, it is different from study conducted by Valintino and Sularto (2013) and Susanto (2012) where profitability is found to partially affect the stock price.

From the results of the regression analysis, it can be seen that simultaneously, the independent variables including Liquidity (CR), Solvency (DER), and Profitability (ROA) have a significant effect on the dependent variable, in this case stock price. This can be proven by the calculated $\mathrm{F}$ value that is higher than the $\mathrm{F}$ table value at the $5 \%$ significant level (F value (11.320) > F table, (3.59)), at the significance value of 0.001 . This indicates that $\mathrm{H} 4$ is accepted proving that Liquidity (CR), Solvency (DER), and Profitability (ROA) simultaneously have significant effect on stock prices.

\section{CONCLUSION AND SUGESTION}

From the results of data analysis and discussion of the study, it can be concluded that it is found that partially, liquidity (CR) and solvency (DER) have no significant effect on stock prices, meanwhile partially, profitability (ROA) has a significant effect on stock prices. Simultaneously, the study found that Liquidity (CR), Solvency (DER), and Profitability (ROA) have a significant effect on stock prices. Furthermore, it was also revealed by the study that the effect of the current ratio, debt to equity ratio (DER) and return on assets (ROA) on stock prices is $68.9 \%$, while the rest is influenced by other factors.

Some suggestions are also given to further researchers. It is expected that future researchers add independent variables and try to increase the research sample. It is also expected that issuers and company management consider the profitability ratio through Return on Assets (ROA) more in making decisions to determine the share price. This is due to the ability of the level of ROA to influence the company's stock price. Some suggestions ar also addressed to investors or potential investors who will invest in a company, not to just rely on this ratio analysis because there are many other factors that are not mentioned in this study that can show the value of a company based on its share price. 


\section{REFERENCE}

Alvionita, R. (2017). Analisis Pengaruh Rasio Likuiditas, Solvabilitas Dan Profitabilitas Terhadap Harga Saham (Studi Pada Perusahaan Retail yang Terdaftar di BEI Tahun 2012-2015) (Doctoral dissertation, Universitas Muhammadiyah Surakarta)

Amanza, A. H., \& Rahardjo, S. N. (2012). Analisis Faktor-Faktor Yang Mempengaruhi Praktik Perataan Laba (Income Smoothing)(Studi Empiris pada Perusahaan Manufaktur yang Terdaftar di BEI Tahun 2006-2010) (Doctoral dissertation, Fakultas Ekonomika dan Bisnis).

Barakat, A. (2014). The impact of financial structure, financial leverage and profitability on industrial companies shares value (applied study on a sample of Saudi industrial companies). Research Journal of Finance and Accounting, 5(1), 55-66.

Brigham, E. F., \& Houston, J. F. (2006). Dasar-dasar manajemen keuangan. Jakarta: Salemba Empat.

Francis, Jack C. (1988), Management of Investment, 2nd ed., International Editions Financial Series, Singapore: McGraw Hill.

Ghozali, I. 2011. Aplikasi Analisis Multivariate Dengan Program IBM SPSS. Semarang: Badan Penerbit Universitas Udayana.

Hanani, A. I., \& MUID, D. (2011). Analisis Pengaruh Earning Per Share (EPS), Return On Equity (ROE), dan Debt To Equity Ratio (DER) Terhadap Return Saham Pada Perusahaan-Perusahaan dalam Jakarta Islamic Index (JII) Periode Tahun 20052007 (Doctoral dissertation, Universitas Diponegoro).

Kesuma, A. (2006). Pengaruh Earning Per Share (Eps) Dan Tingkat Bunga Terhadap Harga Saham (Studi Empiris Pada Perusahaan Food And Beverage Yang Terdaftar Di Bursa Efek Jakarta).

Komala, L. A. P., \& Nugroho, P. I. (2013). The effects of profitability ratio, liquidity, and debt towards investment return. Journal of Business and Economics, 4(11), 11761186.

Kurniawan, H., \& Isynuwardhana, D. (2015). Pengaruh Return On Equity (ROE), Debt To Equity Ratio (DER), Dan Price To Book Value (PBV) Terhadap Harga Saham (studi Kasus Pada Perusahaan Infrastruktur, Utilitas, Dan Transportasi Yang Terdaftar Di Bursa Efek Indonesia Periode 2011-2014). eProceedings of Management, 2(3).

Krisna, A. A. G. A., \& Wirawati, N. G. P. (2013). Pengaruh inflasi, nilai tukar rupiah, suku bunga SBI pada indeks harga saham gabungan di BEI. E-Jurnal Akuntansi, 3(2), 421435.

Mahapsari, N. R., \& Taman, A. (2013). Pengaruh Profitabilitas, struktur aktiva, dan pertumbuhan penjualan terhadap harga saham dengan struktur modal sebagai variabel intervening pada perusahaan manufaktur di Bursa Efek Indonesia. Nominal: Barometer Riset Akuntansi dan Manajemen, 2(1), 137-158.

Menaje, P. M. (2012). Impact of selected financial variables on share price of publicly listed firms in the Philippines. American international journal of Contemporary Research, 2(9), 98-104.

Mittelstaedt, H. F., \& Warshawsky, M. J. (1993). The impact of liabilities for retiree health benefits on share prices. Journal of Risk and Insurance, 13-35.

Mulyadi. 2006. Manajemen Keuangan Pendekatan Kuantitatif dan Kualitatif. Jilid 1. Malang: Bayumedia Publishing.

Murniati, S. (2016). Effect of Capital Structure, Company Size and Profitability on the Stock Price of Food and Beverage Companies Listed on the Indonesia Stock Exchange. Information Management and Business Review, 8(1), 23-29.

Murtanto dan Harkivent. 2000. “Analisis Pengaruh Infromasi Laba”, Jurnal Ekonomi, Vol.6 No.3, hal. 992-1021. 
Noverio, R., \& Dewayanto, T. (2011). Analisis Pengaruh Kualitas Auditor, Likuiditas, Profitabilitas dan Solvabilitas Terhadap Opini Audit Going Concern pada Perusahaan Manufaktur yang Terdaftar di Bursa Efek Indonesia (Doctoral dissertation, Universitas Diponegoro).

Ojah, H. K., Malik, Y. S., \& Ali, A. M. M. (2019). Capital solvency and its impact on the stock prices of banks Listed on Iraq Stock Exchange- Applying to National Bank of Iraq. International Journal of Multidisciplinary Research and Publications (IJMRAP), 2(5), 31-36.

Prayitno, A. (2008). Pengaruh Profitabilitas, Solvabilitas, dan Likuiditas Terhadap Harga Saham Sektor Properti di Bursa Efek Jakarta Tahun 2001-2006 (Doctoral dissertation, Universitas Widyatama).

Rinati, I. (2012). Pengaruh Net Profit Margin (NPM), Return On Assets (ROA) dan Return On Equity (ROE) terhadap harga saham pada perusahaan yang tercantum dalam indeks LQ45.

Setiyawan, I., \& Pardiman, P. (2014). Pengaruh Current Ratio, Inventory Turnover, Time Interest Earned dan Return on Equity terhadap Harga Saham pada Perusahaan Manufaktur Sektor Barang Konsumsi yang Terdaftar di BEI Periode 20092012. Nominal: Barometer Riset Akuntansi dan Manajemen, 3(2), 117-133.

Shaheen, S., \& Malik, Q. A. (2012). The impact of capital intensity, size of firm and profitability on debt financing in textile industry of Pakistan. Interdisciplinary Journal of Contemporary Research in Business, 3(10), 1061-1066.

Suad Husnan dan Enny Pudjiastuti. 2012. Dasar-Dasar Manajemen Keuangan. Yogyakarta: UPP STIM YKPN.

Susanto, A. S. (2012). Pengaruh Likuiditas, Profitabilitas, Solvabilitas dan Ukuran Perusahaan Terhadap Harga Saham Perusahaan Farmasi di BEI. Jurnal Akuntansi Unesa, 1(1).

Susilawati, C. D. K. (2012). Analisis Perbandingan Pengaruh Likuiditas, Solvabilitas dan Profitabilitas terhadap Harga Saham pada Perusahaan LQ 45. Jurnal Akuntansi, 4(2).

Susilowati, Y., \& Turyanto, T. (2011). Reaksi signal rasio profitabilitas dan rasio solvabilitas terhadap return saham perusahaan. Dinamika Keuangan dan Perbankan, 3(1), 17-37.

Tahu, G. P., \& Susilo, D. D. B. (2017). Effect of Liquidity, Leverage and profitability to The Firm Value (Dividend Policy as Moderating Variable) in Manufacturing Company of Indonesia Stock Exchange. Research Journal of Finance and Accounting, 8(18), 2222-1697.

Valintino, R., \& Sularto, L. (2013). Pengaruh Return On Asset (ROA), Current Ratio (CR), Return On Equity (ROE), Debt To Equity Ratio (DER), dan Earning Per Share (EPS) Terhadap Harga Saham Perusahaan Manufaktur Sektor Industri Barang Konsumsi di BEI. Prosiding PESAT, 5.

Zuliarni, S. (2012). Pengaruh Kinerja Keuangan Terhadap Harga Saham Pada Perusahaan Mining and Mining Service di Bursa Efek Indonesia (BEI). Jurnal Aplikasi Bisnis, 3(1), 36-48. 